Sexual and Political Liberty and neo-Latin Poetics: the Heroides of

Mark Alexander Boyd.

\title{
EDWARD PALEIT
}

\begin{abstract}
This article examines responses to the Heroides by the Scottish neo-Latin poet Mark Alexander Boyd, composed whilst in 'exile' in France during the 1580s and early 1590s. Boyd's engagements reflect the priorities of contemporary humanist interpretations of the Heroides, on the one hand positioning Ovid's poems as models for elegant Latin verse composition, and on the other reading them as guides to female sexual (mis)conduct. Such an approach tended to reinforce Renaissance prejudices about sex and gender, as Boyd's efforts amply reveal. Yet the exorbitance of female love elegy also permitted a limited critique of such norms, and this is demonstrated in Boyd's second set of responses, the Heroides et Hymni (1592), which suggestively collocate his personal political difficulties with women's sexual freedom.
\end{abstract}

\section{Keywords:}

Boyd, Mark Alexander (1563-1601)

Neo-Latin poetry

Love elegy

Renaissance humanism

Reception of classical texts

Heroides

Freedom

Sex

Women 
During the sixteenth century, Ovid's Heroides inspired a number of vernacular and neo-Latin responses. Many of these works were replies in the literal sense, developing a tradition of answering Ovid's heroines which had started within their author's lifetime, as he records in Amores II.18. ${ }^{1}$ Other writers, like the Englishman Michael Drayton, took the poems largely as models for plaintive poetic epistles of their own devising, as appears elsewhere in this collection.

The Scottish neo-Latin poet Mark Alexander Boyd (1563-1601) was unusual in attempting both forms of engagement. In the late 1580s, he composed replies to the first fifteen of Ovid's Heroides by their male addressees. These were published in 1590 in a work entitled 'Fifteen Epistles' (Epistolae Quindecim), although it also contained other elegies and a series of epigrams. ${ }^{2}$ Boyd was dissatisfied with these responses, however, later telling a friend they were inferior to his subsequent efforts. ${ }^{3}$ In 1592 a second volume of poetry appeared, the Heroides et Hymni. This work contained imitations, not replies: fifteen Latin elegiac epistles, all by women to men, all unanswered (like the first fifteen of the Heroides), all using situations from antiquity, although unlike Ovid employing historical as well as mythical settings. ${ }^{4}$ This volume also had other matter - fifteen themed neo-Latin 'Hymns' supposedly modelled on Orpheus, letters in Latin between Boyd and various acquaintances, and a sprinkling of epigrams by Boyd and others in Latin and Greek. It was dedicated to James VI of Scotland as proof, so the epistle ran, of Boyd's political devotion. ${ }^{5}$ Possibly because of this dedication, Boyd's poems have sometimes been regarded as part of the Ovidian turn in Scottish poetry encouraged by James during the 1580 s. ${ }^{6}$ Yet although Boyd may have known this fashion, his works are in no sense products of Scottish culture. In fact he had left Scotland in 1581, aged nineteen, in hazy but problematic 
circumstances which alienated him from most of his family. ${ }^{7}$ He spent much of his time in France, sometimes as a mercenary in the civil wars; both his works were published there. As I.C. Cunningham has observed, political and religious factors, as well as the scandal later alleged by Scottish antiquarians, were probably responsible for this exile, which plays a role in his engagements with Ovid. ${ }^{8}$

Why imitate the Heroides so soon after composing replies to them? Indeed, why respond to them at all? The answer, so this article argues, lies partly in two related contexts: firstly, contemporary humanist scholarship, in terms both of commentaries on the Heroides of the later sixteenth century and also humanist ideas of the amorous elegiac complaint, of which Ovid's epistles (and Boyd's imitations) are notable examples; secondly, Boyd's personal circumstances, motives and concerns. It also lies, of course, in the poems themselves. The overall aim is to throw light on responses to the Heroides and indeed classical texts in general in the late sixteenth century.

\section{Boyd, neo-Latin poetics and the Heroides.}

Humanist attitudes to the Heroides always had a strong pedagogical element. They were seen as accomplished poems suitable for instructing pupils on the reading and writing of elegant Latin verse, it being the humanist view that this was a desirable social and political skill. Editions of Ovid's work advertise its suitability for schoolboys and one even provides before the text some 'charmingly and prettily spoken' excerpts from the text, presumably for absorption into a student's own copia. ${ }^{9}$ Boyd's engagements with the Heroides also reflect a distinctively humanist emphasis on elegant Latin composition. ${ }^{10}$ In a prefatory epistle to his 1590 volume, 
he tells his reader that to respond to Ovid, one must reproduce him. ${ }^{11}$ It turns out he means reproducing Ovid's stylistic and linguistic excellency, not his content, which the epistle hardly mentions. Few can follow, he declares, Ovid's urbane polish in connecting verses, or for that matter his 'inborn elegance of Roman speech: nothing broken, nothing dark, nothing affected'. ${ }^{12}$ This commendation is at root simply praise for Ovid's grammatical purity or Latinitas. Today we are unlikely to find this aspect of his poetry very interesting, but for Boyd, saturated in Renaissance humanist culture, it invites admiration and even a little mystique: no-one will think he has 'Ovid's innate impetus to art [...] who does not reckon himself born under the same star with him, as if he is returning'. ${ }^{13}$ In dedicating the 1592 Heroides et Hymni to James VI, Boyd turns away from Ovid specifically, but only to consider the form of (and not content) of Latin elegy in general. Although several modern poets 'have been outstanding in every genre,' he here claims, 'there has been none to give this age a clean, slight and neat elegy in good Latin'. ${ }^{14}$ Even the Romans struggled: 'Propertius was too erudite and Tibullus too safe and neat; to these Ovid added slightness and the vigour he was born with - he was the best of the ancients'. ${ }^{15}$ Boyd thus implies he will be the first to get elegy completely right, using Ovid as model. If these remarks are taken seriously, then Boyd's responses to Ovid are largely about fulfilling various stylistic or formal proprieties in order to measure himself against a critically graded universe of ancient and modern practitioners. Indeed, according to his descriptive vocabulary ('tersam', 'tenuem', 'concinnam'), elegy is in itself a slight, somewhat inconsequential verse form - the chief significance of his engagements therefore lies in his demonstration of cultivated facility. Of course such facility is intended to carry enormous prestige, and it allows Boyd to present his 1592 volume to his king as proof of political worth, as his dedicatory epistle to James makes clear: 
I ask that out of your accustomed clemency you regard this slight picture, which I fasten to the altar of Memory in your name; behold me as one not only born for you, but always free from all foreign patronage in the hope of your favour. ${ }^{16}$

Indeed the 1592 volume makes further efforts to secure James's goodwill, not only including Greek and Latin epigrams dedicated to him, but also a themed hymn, 'Hasta [spear]', which provides a mythical aetiology of the weapon, addressing James as 'distinguished father of [my] muse'. ${ }^{17}$ The cultural assumptions of Renaissance humanism thus allow Boyd's poetic competence to pass as eligibility for service. In Boyd's case it is almost certainly not only patronage but rehabilitation which is being asked for: letters between him and Patrick Sharp, the rector of Glasgow University, dwell anxiously upon strategies for approaching James, and the possible difficulties aroused by Boyd's past. ${ }^{18}$

\section{The humanist Heroides and sexual and gender politics.}

This way of reading Boyd's Heroides only gets us so far, however. For one thing it is not entirely true to say that humanists' linguistic concerns produced an indifference to content. One theme of Ovid's original epistles certainly aroused repeated interest: the sexual conduct of women. In a 1574 edition, for example, the commentator Hubertinus states that:

Really the subject-matter is ethical, i.e. moral, because it describes the different moral conduct of [?]men and women. The poet's intention is by exercising his intelligence and investigating the form of love to demonstrate its effects, and to show how much they differ between shamefast [pudicis] and shameless [impudicis] women, so that they prove in some the piety of chaste love and in others the incontinence of lust and madness. Therefore some women are commemorated for the purpose of praise and imitation, and others for the sake of abhorring lust and shamelessness [impudicitiae]. ${ }^{19}$ 
Ovid's women, it is here argued, invite classification according to a fixed standard of sexual morality called pudicitia; the Heroides is therefore an epideictic text, inciting imitation or aversion regarding sexual conduct. A later edition contends that Ovid wished to fit his heroines 'to the propriety and moral conduct of women who are accustomed to speak purely and uncorruptly through domestic usage, not reason' ${ }^{20}$ Here grammatical concerns and sexual morality coincide: indeed this edition, which prints the list of 'charmingly and prettily spoken' sayings mentioned above, also includes, at the very front of the volume, another list of sentences from the Heroides that are spoken 'honestly and knowledgeably'. ${ }^{21}$ The recurrent theme of this list is sexual propriety - they include, for example, 'shamefulness [pudicitia] harmed is instantly destroyed' (from Oeneone's epistle), or 'virtue is to have abstained from former pleasures' (from Helen's): in short, a neat catechism of female sexual decorum..$^{22}$

Yet what was pudicitia, the term so often employed by these writers? As Julius Caesar Scaliger helpfully explains in his influential treatise Poetices Libri Septem (1561) it is the 'virtue proper to a woman' and means 'abstaining from prohibited sex', i.e. sex outside marriage. ${ }^{23}$ It was not a subjective state but a continued practice - an Anglo-Latin dictionary of 1578, for example, defines it as 'cleannesse of living' . ${ }^{24}$ It contrasts with pudor, a term now often translated as 'shame' and usually signifying an interiorised emotional response. The same dictionary, however, defines pudor rather differently, as 'moderation [i.e. the imposition of modus or limits] letting the minde to doe any thing wantonly or dishonestly' - it means active self-control, the policing of the boundaries to pudicitia. ${ }^{25}$ The forfeiture of such control, as Hubertinus's remark above makes clear, produces incontinence and frenzy.

Reading the Heroides as a manual of female sexual and gender proprieties may challenge or upset modern readers, especially ones unfortunate enough to like 
Ovid. We are trained to identify subtexts in classical and Renaissance poetry, and indeed Ovid has recently been seen as something of a subversive. ${ }^{26}$ We are also, we like to think, guided by fidelity to writers' original sense. Yet we should allow for the possibility that this is how Renaissance humanists did in fact see Ovid's text. Maybe they saw no subtexts; maybe they found it as impossible to think beyond a judgmental, gendered moralism as we might to return to a formalist aesthetics. Nor was there any necessary incongruity in taking Ovid (of all poets) as a guide to sexual morality during this period. In the Anglo-Latin dictionary already cited, there are 109 citations from classical authors for the nouns pudicitia and pudor, the related adjective pudicus and adverb pudice. Ovid accounts for forty-seven of them; the next most cited, Cicero, for less than twenty. ${ }^{27}$ Ovid as the voice of chastity, perhaps? - the idea has a pleasing perversity. And in fact reading the Heroides as if its author did preach pudicitia is easy enough. One simply awards Ovid's women marks for correct sexual conduct. The heroine of Epistle I is the loving, suffering Penelope - she is clearly pudica. On the other hand Phyllis, in Epistle II, who sleeps with Demophoon only to have him abandon her, is the opposite. She says so herself: sleeping with Demophoon was 'shameful' (turpiter); she would still be respectable (honesta) if she'd only died beforehand; her suicide will compensate for her 'tender shame [tenerum pudorem]'. ${ }^{28}$ Crude the hermeneutics may be, but it works.

It should be unsurprising to find the Heroides read for instances of female irrationality associated with sexual misconduct. In the later sixteenth century, the very form of love-elegy encouraged such expectations, marking a difference in this respect from classical treatments. In antiquity, 'elegies' had largely meant poems using the hexameter/ pentameter couplet; Greek elegists wrote on a variety of topics. Renaissance humanists, contrastingly and perhaps revealingly, tended to understand elegy through its major Latin exponents, Tibullus, Propertius, and Ovid. They 
consequently characterized it mostly as a complaint by distressed lovers, typically men. This thematic understanding of elegy became normative by the end of the sixteenth century. In England, for example, the vernacular theorist George Puttenham wrote in his Art of Poetrie (1589):

There was an other sort, who sought the fauor of faire Ladies, and coueted to bemone their estates at large, \& the perplexities of loue in a certain pitious verse called Elegie, and thence were called the Elegiack: such among the Latines were Ouid, Tibullus \& Propertius. ${ }^{29}$

A definitional slippage from meter to situation in part reflects the rise of vernacular poetry, in which classical quantitative meter was rarely used. In the sixteenth century, vernacular 'elegy' nearly always means amorous complaint, not a given rhythm or form. In England (to continue this example) there was a vogue for such elegiac outpourings in the late sixteenth century, pronounced enough to cause the satirist Everard Guilpin to bemoan a surfeit of 'puling Elegies' in his Skialetheia of $1598 .{ }^{30}$ It is easy to see that the Heroides fit this mould of elegiac complaints, even without noting their repetitious use of querela and queror. ${ }^{31}$ Renaissance commentators like Hubertinus make the point that the elegaic form is particularly suited to the text's plaintive, amorous content. ${ }^{32}$

More importantly, making amorous complaints of this type was taken to indicate mental instability. One of the most revealing discussions here is Scaliger's in his Poetices, as it connects love-elegy not only to irrational conduct but specifically to irrational conduct by women. In explaining the historical transition in elegy from funeral laments to lovers' ones, Scaliger produces the following argument:

For complaint [conquestio] is frequent in situations of love [amoribus]; and the truest death is that which is lived by us, in our greatest madness [amentissimis] for the maddest [amentissimo] and most ungrateful sex. ${ }^{33}$ 
Here the punning link between love and insanity (amor, amentissimo, amentissimis) ascribes men's madness for women to the madness of women, implying that men are feminized when they succumb to the destabilizing attractions of the unstable sex. This implication is confirmed by Scaliger's terminology. His word for elegiac complaint here, conquestio - later he describes elegy as 'suited to complaints [conquestionibus]' - he also employs for typical female behaviour in a chapter on women in poetry. ${ }^{34}$ This chapter commences by asserting that women are by nature 'faithless, suspicious, inconstant, treacherous, dissembling and superstitious' ${ }^{35}$ It argues that their lack of moderation explains a predisposition to complain. ${ }^{36}$ Indeed, Scaliger claims:

Truly they fall headlong into weeping and conquestionem [...] for that sex is insatiable in all matters, such that it cannot be placated when it desires something nor satisfied when it has obtained it. It is never satisfied with its lot. ${ }^{37}$

This remark, as well as emphasising the gendered associations of conquestio, also draws attention to the exorbitance of female complaint - it seems to overflow the circumstances which provoke it, becoming unfocused and generalised. It is significant to note that Scaliger seems to attribute this plaintive excess to deeper dissatisfaction with the 'lot' of women in general, their socio-political situation, as opposed to the specific crisis faced by any particular woman.

These remarks, together with those of humanist commentators, give us a framework for understanding the ambivalences in approaches to the Heroides in the later sixteenth century. At one level they are asserted to be manuals of female pudicitia, laid out in Ovid's elegant classical Latin. However, as excessive and irrational complaints, they also threaten to overwhelm the speaker or poet - who 
tends to be male - with an instability and propensity to sexual misconduct that is thought about chiefly in relation to women. Female love elegy thus comes to figure the tensions implicit in Renaissance notions of gender. It is significant that when Scaliger discusses the elegiac meter he is led to define it as a microcosm of gender relations: 'the variable [fluxus] pentameter is placed beneath/subjected to [subditur] the constant heroic [meter]' ${ }^{\prime} 8$ The politics is hardly encoded here: in Renaissance discourse a monarchical subject was a subditus. The elegiac meter expresses the threat posed by variable, faithless women to a heroic male singularity which ought to hold them in subjection.

As we shall see, however, Scaliger's rabidly misogynistic conclusions need not always follow from thinking about the Heroides along these lines. As his own discussion suggests, there is a moment in Renaissance versions of the female complaint when the woman's discourse does not so much lose focus as refocus on the more general cultural and political inequities which lie behind her personal difficulties - when plaintive exorbitance permits a move from local emplotment into political critique. That very move is, it will be argued, identifiable also in Boyd's later engagements with the Heroides.

\section{Political and sexual liberty in Boyd's Heroides.}

In Boyd's earlier collection on other hand, the Epistolae Quindecim (1590), there is little to indicate any such critique taking place. He is largely concerned with putting the man's side of the case, thereby reasserting gender roles. He feels this is necessary, telling his reader that the original Heroides demand replies. ${ }^{39}$ Many of his 1590 epistles indignantly refute the charges of sexual impropriety levelled by Ovid's 
heroines, whilst accusing them in turn of frenzy, fantasy and incontinence. Boyd's Demophoon, to take one example, is not Ovid's absent philanderer but a loyal lover, returning to Phyllis as soon as he can. He denies he has another wife, as Ovid's Phyllis suspected, instead emphasizing the exorbitant 'savagery' (ferocia) and 'anger' (ira) of Phyllis's allegations. ${ }^{40}$ Later he tells Phyllis brusquely to 'cease more complaining' ${ }^{41}$ This refrain can be found in other epistles - Hercules, for example, tells Deianeira to 'stop producing cruel complaints'. ${ }^{42}$ A drive to stop the women complaining suggests that Boyd's 1590 replies are partly anti-elegies, which attempt to deflate or counter the querulous female superfluity of the Heroides.

The Epistolae Quindecim also attempt to assert gender differences in their representations of men. Boyd's Hercules, for example, is a wholly masculine figure; he passes over the charge by Ovid's Deianeira that he wore women's clothes and took up weaving. ${ }^{43}$ One accusation he is less able to avoid is adultery. Hercules, however, simply takes it as proof that he is a man, indeed that he is Hercules - his legendary strength (robur) is equated with spreading his seed. 'Doubtless a man who contains his mighty strength in his breast could live in the solitary bed of one woman,' he argues 'and is, as it were, always there at your nod':

But where would indefatigable Hercules be then, where his strength, his club, if I who vanquish others, would be vanquished by you? ${ }^{44}$

Hercules's 'club' (clava) here signifies the necessary promiscuity that he believes accompanies phallic potency. It won't be a small honour for you, woman,' he informs Deianeira, 'if you were the wife of Hercules along with many others'. ${ }^{45}$ We are almost certainly deceived if we try to read into this a critical exposure of sexual double standards. Boyd's own argumentum to the epistle, explaining Hercules's viewpoint, states that it wouldn't be 'fair that Hercules, who beat everyone else, 
obeyed one woman alone' ${ }^{46}$ Monogamy compromises male supremacy. The underlined fact that the invincible Hercules is defeated by a woman actually reinforces gender prejudices - the epistle's concluding couplet recalls Scaliger's gendered reading of the elegiac couplet in stating it was not violence or one of his labours that did for Hercules, but a woman's base trickery: heroic masculinity is undone by female fraudulence. ${ }^{47}$

To an extent Boyd's later Heroides et Hymni (1592) is driven by similar concerns. His heroines are frequently aware of the need to confine sex to marriage, expressing shame (pudor) when they don't. In the first epistle, for example, Atalanta invites Meleager to do things with her which she is 'ashamed to speak of [pudet loqui]'. ${ }^{48}$ Paulina, assaulted in the temple of Osiris, tells her rapist that he broke the bonds 'which connubial love tied together' ${ }^{49}$ Such insistence on matrimonial fidelity does not exclude, however, a salacious interest in extra-marital sex. Lamia's letter to Demetrius, for example, is structured around a central narrative in which she attempts to revive his flagging sexual ardour by recalling the first time they made love. Boyd states in his argumentum that this epistle is 'entirely about Venus', that is having sex, and there is little doubt that its main purpose is pornographic, with a male reader in mind. ${ }^{50}$ Euphemism mixes with explicit suggestion: 'my features became wilder and grew flushed, my little eyes moved more rapidly,' Lamia records excitedly, 'and being stimulated I was in agony at my own movement'. ${ }^{51}$ Yet, as so often with pornography, such erotica serves to reinforce a prescriptive sexual morality. Lamia herself advertises the improper transgression of boundaries as she and Demetrius made love. 'Golden shame [pudor], and all cultivation of correct conduct [honesti], was expelled', she declares. ${ }^{52}$ Moreover, as both Boyd's argumentum and the poem itself explains, Demetrius loses sexual interest chiefly because his affections are transferred from an affair with Lamia, a mere 'psaltria' or 
female musician, towards a woman he is hoping to marry fitting his royal rank. ${ }^{53}$ The epistle's reader need not worry that titillating, drunken sex with a servant dissuades from marriage's sacred institution.

Yet in the Heroides et Hymni Boyd writes as women, not as men; and this does generate a more complex, conflicted attitude to gender and sexual proprieties. At the end of Boyd's argumentum to the Lamia epistle, for example, he frets about the implications for his own chastity in writing with such female abandon. 'The poet', he states of himself, 'does not wish what is appropriate to the person of Lamia to be inappropriate to him in his purity'. ${ }^{54}$ This anxious separation of gender roles can also be detected in his 1592 collection in his ambivalent reaction to some Greek and Latin poetry sent him by an actual woman, Maria Tiraquella. ${ }^{55}$ Boyd dedicates one of his hymns to Tiraquella, whom he enthusiastically compares to the ancient Greek poets Teresilla and Corinna as well as Theano, the gifted wife of Pythagoras. ${ }^{56}$ Yet worries about usurpation of male privileges are not entirely displaced here: the hymn's theme turns out to be 'linum' or flax, and largely expounds a mythical aetiology of the development of weaving, using the myth of Arachne from Ovid's Metamorphoses. ${ }^{57}$ Boyd praises Arachne's achievement and also takes her side in her famous contest with Minerva (though only in passing). ${ }^{58}$ But he opens by portraying the whole poem as a weave, and at its close downs the shuttle with evident relief, alluding to Hercules's feminized enslavement by Omphale, during which he took up weaving. ${ }^{59}$ Making textiles is women's work, he thus implies: the hymn ultimately seeks to rebuke a woman's poetic aspirations and distinguish gender roles once again.

Nonetheless Tiraquella evidently stirred up Boyd's attitudes to sex and gender more than this hymn suggests. The 1592 volume includes an effusive prose letter to her, which uses her poetry as an occasion for making a striking recantation 
of male prejudice against women writers. ${ }^{60}$ Passing through a series of arguments such as the sex of Minerva, the Graces and the Muses - Boyd claims that women's current position reflects an historical injustice: 'I would never believe the inclemency of men has gone so far as to expel you from your ancient possession of loves [venerum] and eloquence'. ${ }^{61} \mathrm{He}$ then expounds a myth in which men robbed women of their freedoms, loosely based on the defeat of the Amazons:

When once you used to contest the highest prize with us, you were beaten in battle and by the law of nations made our serving-maids; whenceforth you have been in the full ownership and power of our sex, whether we are husbands, parents or masters; and not only have you been secluded from public responsibilities, but also forbidden fraternization with your ancient sisters, the muses and the loves [venerum], lest you should ponder your situation and your ancient dignity. ${ }^{62}$

Poetic composition and sexual love were arts where women once ruled, but from whose possession they were forcibly expelled when they became subjected to men.

Such arguments are not those of a modern feminist, of course. Boyd suggests women were enslaved justly, by the ius gentium, no idle precept for one trained in the civil law. ${ }^{63}$ It is difficult to gauge the sincerity of his set-piece arguments, such as the sex of the Muses. Finally attributing primacy in sexual matters to women has overtones of male erotic fantasy and can also be read moralistically, as in the Lamia epistle. But when we re-examine the climax of that very elegy we find a similar argument. Lamia attacks the whole institution of marriage:

Lamia lies alone on fire on the bed, her slothful lover grows cold, and Lamia is alone on her lukewarm bed. Ah, he who first joined lovers in marriage, and forbade them to follow the free deeds [libera facta] of the Paphian goddess [Venus]: may he be suspended in the midst of waves, like thirsty Tantalus, nor may food be brought to assuage his dread mouth! ${ }^{64}$

Like Boyd's letter to Tiraquella, Lamia here invents a mythical aetiology to explain the loss of the 'free deeds of Venus'; it is the dismal consequence of the imposition of 
marriage on lovers by an unknown agent. To be sure, portraying a lustful concubine moaning for greater satisfaction while the male reverts to social norms is stereotypical. Yet Lamia's grievance is exactly that form of exorbitant female complaint that passes into political critique discussed earlier. It conceptualizes marriage as an historical institution, the foundation of difference and dislocation in sexual love.

This note of sympathy for women's lot was not entirely foreign to the 1590 volume. The Epistolae Quindecim had in fact ended with a set of 'eulogies' on famous women, including some of Ovid's heroines and ones who later appear as speakers in the Heroides et Hymni. ${ }^{65}$ There is nonetheless greater evidence of sexual and gender radicalism in the later collection. Boyd's epistle from a dead Eurydice to Orpheus, for example, even essays critical reflection on pudicitia itself, one of the controlling terms of humanistic sexual-moral discourse. Eurydice's poem concludes with a serious reflection on the moral pressures informing a woman's sexual options. The immediate cause of her death is a snake-bite when fleeing from a would-be rapist, Aristaeus. ${ }^{66}$ Aristaeus, however, has a minimal presence in Boyd's poem. The real cause was Eurydice's pudicitia: the snake 'stole me away whilst I was protecting the dear rights of pudicitia', she states in the final couplet. ${ }^{67}$ She comments with bitter insight on this moral impulse, contrasting human experience with doves:

But shame and fear and a concern for dear chastity produce the seeds of human disease. The concern oppresses weak women, but a girl is only wise [sapit; in this context, 'has such knowledge, is wise to this'] who has, deathly pale, revealed her wounds. ${ }^{68}$

Boyd here implies that Eurydice, with the hindsight of death, sees human sexual decorum as having a debilitating effect, especially on women. Naturally a very unfeminist interpretation of this sentiment can be given. Are women better off sexually 
available? Should Eurydice have let herself be raped by Aristaeus? Nor is there a sense that such moral pangs could be avoided: the human disease mentioned here is almost certainly the sexual shame of original sin in Christian theology. But on the other hand this may be exactly what Eurydice, participating in one of the greatest non-Christian myths, is protesting about. The disease is less sex than the shaming regime of pudicitia through which it is thought and expressed.

Another example of a changed perspective is Boyd's view of Aeneas, the recipient of an accusing letter from Dido in Ovid's Heroides. In the 1590 collection, Aeneas replies to Dido in an epistle modelled closely in structure and tone on Aeneas's self-justifying speech in Virgil's Aeneid, reiterating his duty to divine and family destiny and denying any sexual misconduct. ${ }^{69}$ Contrastingly, the 1592 volume contains a verse epistle from Lavinia, the destined bride of Aeneas, to Turnus, Lavinia's original betrothed and Aeneas's tragic opponent. Although Lavinia counsels Turnus not to struggle against destiny and be killed, she condemns Aeneas as a 'savage' (ferus) and 'perfidious' (perfidus) criminal, who sold Troy for gold and was responsible for Dido's death. ${ }^{70}$

Finally in one epistle the Heroides et Hymni uses female complaint to attack the ruler with whom Aeneas was often associated, and thereby reflect bitterly on the fate of Ovidian poets like himself. This is the epistle from Julia to Augustus, the father who exiled her. Historically Julia's punishment was for adultery and was connected in some unspecified way with Ovid's banishment to Tomis. Boyd's epistle makes Ovid's punishment Julia's central grievance. Arguing that there had never been a more gifted Roman poet, she describes Ovid as 'deserving [merenti] and innocent [insonti]'; there was no-one 'more chaste [castior]' in the whole city, she claims. ${ }^{71}$ Julia's bitterness soon becomes politically radical: she claims that Ovid would have got his deserved recognition had Rome retained her 'ancient imperium' 
and been 'free [libera]'. ${ }^{72}$ Such republican language accompanies revelations about Augustus's murderous conduct and aphorisms on the horrors of tyranny.

Complaining that there is no Cassius or Brutus to repeat Julius Caesar's tyrannicide, Julia works herself up to denying that Augustus is her father altogether: a good example of a woman's exorbitant elegiac outburst working to produce political critique. ${ }^{73}$ Nor is her conquestio political simply in an anti-tyrannical sense. She also turns on its head the standard charge against Ovid, that he encouraged sexual immorality:

When Ovid, the teacher of adultery, who willingly has Julia as a whore, exceeded legitimate moderation in his wrath, he said, 'Caesar is chaste, until Livia the procuress casts him a girl, then hides the deed in her pious heart. A crowd of old men are her [Livia's] companions, but the adulteress is always Julia, even though she has been neither looked over nor accompanied by a man. ${ }^{74}$

This passage is bitterly sarcastic. Many of its terms deserve inverted commas: the "chaste" Caesar, the "whore" Julia, Ovid the "teacher of adultery". Boyd here treats the first Roman emperor not as the admired patron of courtly Augustan poets but as the hypocritical lecher of Suetonius's biography, from which most of his details are lifted. ${ }^{75}$

The Julia epistle clearly throws across Boyd's identity as an Ovidian poet the shadow of the Tristia and Epistulae ex Ponto. It almost certainly refers at some level to his own situation as a Scottish exile, and defiantly too (his Ovid is no sense guilty of his alleged crimes). Once this identification is accepted, it is difficult not to see a provocative comparison of James VI, the dedicatee of the 1592 collection, to a tyrannical Augustus. Other evidence suggests there may have been a certain bitterness underlying Boyd's forced approach to his sovereign. We know from his correspondence that he chafed under the requirements of subjection; both he and his 
friends refer to his love of liberty. ${ }^{76}$ Indeed, he found the advice of his friend and mentor Patrick Sharp difficult to stomach:

You advise me to attend the king like a Persian. I will do whatever I can. To be sure, I bind myself over daily with a snivel, yet bravely and after my own fashion, as one who judges life not greatly to be pursued without praise. ${ }^{77}$

For Boyd, submissiveness to his monarch was uncomfortably similar to being an Oriental despot's lackey. To be sure, the fact that this letter to Sharp, like Julia's epistle, was printed in a book addressed to James makes it difficult to argue that Boyd was a hardened ideological opponent of his king. Oppositional radicalism of that kind is hard to find in sixteenth-century Europe. But it does sound a note of warning nonetheless. Boyd's loyalty is not to be had upon servile conditions; rulers obtain obedience only when they respect a subject's independence and need for honour (laus, in the above extract), not when they peremptorily punish deserving poets. It is worth adding that Boyd never did earn an honourable return to Scotland, revisiting it only briefly after his father's death in 1595 . He died abroad in 1601, ending his life, like Ovid, in exile.

\section{Conclusion: Boyd's Heroides and Renaissance engagements with classical texts.}

That the Heroides could function as a vehicle for such feelings, as well as much else, should alert us to the complexity of interpreting early modern engagements with classical poetry. Ancient literature occupied a position in sixteenth-century culture very different from its position in ours. Ways of reading 
were marked by normative assumptions about what reading was for, let alone how conducted, that we no longer share and are unlikely to respect. Furthermore works like the Heroides was examined from perspectives heavily conditioned by contemporary prejudices about sex and gender. Recognizing these interpretive filters is indispensable for sensitive historical interpretation of the Renaissance reception of such texts. On the other hand, Boyd's responses suggest it would be mistaken to see Renaissance frameworks of reading as having placed their controlling assumptions entirely beyond dispute, or as rigidly prescribing the character of particular engagements. Every reader and writer is, after all, ultimately unique: no-one else has their combination of words, just as no-one else has their specific trajectory through time and space. The normative is always reworked by the individual.

Boyd's poetry is a good example of how personal experience - in his case quite a troubled one - gave his responses to Ovid a unique inflection. It is clear, on the one hand, that humanistic ideas about neo-Latin poetry and early modern sexual and gender proprieties heavily structured how he read and responded to the Heroides. His pen moved along paths worn deep by past commentators and theorists. But he was able, nonetheless, to consider reflectively the issues he confronted as he went. We can identify in his poetry a steady problematization of certain Renaissance ideas about sex and gender, to the extent that in his Heroides et Hymni he entertained some idea of a situation in which women were not sexually or artistically subordinate to men and represented ideas like pudicitia critically. This was certainly not a teleological arrival at a modern feminist viewpoint - Boyd's sense of female liberty was partly rhetorical, partly pornographic, and infrequently visible. But nor was it some ghastly, accidental discovery. One can even argue that its effect was precisely liberating for Boyd. His Julia epistle implies at the very least an imaginative link, a congruence of thought, between womens' sexual freedom and the political 
liberty of the subject. Though a minor humanist poet of no great talent, Boyd's ability to feel his way towards such conclusions may well constitute his principal interest for modern cultural historians.

Edward Paleit

Birkbeck College, University of London 


\begin{tabular}{|c|c|c|c|c|c|}
\hline \multicolumn{6}{|c|}{ Appendix: The 'Heroides' in Boyd's Heroides et Hymni (1592) } \\
\hline Ep. & Female writer & Addressee & Situation & & Source \\
\hline I & Atalanta & Meleager & Sexual invitation & & Myth \\
\hline II & Calliroe & Diomedes & Complaint (abandonment) & Myth & \\
\hline III & Rhea Silvia & Mars & $\begin{array}{l}\text { Complaint (rape, } \\
\text { impregnation) }\end{array}$ & & Myth \\
\hline IV & Antigone & Haemon & Warning (tyranny) & & Myth \\
\hline $\mathbf{V}$ & Lamia & Demetrius & $\begin{array}{l}\text { Complaint / sexual } \\
\text { invitation }\end{array}$ & History & \\
\hline VI & Eurydice & Orpheus & Complaint & & Myth \\
\hline VII & Clytia & Phoebus & Complaint (rejection) & Myth & \\
\hline VIII & Lavinia & Turnus & $\begin{array}{l}\text { Complaint / invitation to } \\
\text { elope }\end{array}$ & & Myth \\
\hline IX & Philomela & Tereus & Complaint (rape) & & Myth \\
\hline $\mathrm{X}$ & Sophonisba & Massinissa & $\begin{array}{l}\text { Promise (fidelity and } \\
\text { suicide) }\end{array}$ & $\mathrm{y}$ & Histor \\
\hline XI & Paulina & Mundus & Complaint (rape) & & Histor \\
\hline XII & Thisbe & Pyramus & Complaint (separation) & $\mathrm{y}$ & Myth \\
\hline XIII & Julia & Augustus & Complaint (tyranny) & & Histor \\
\hline XIV & Octavia & Antonius & Complaint (abandonment) & $\mathrm{y}$ & Histor \\
\hline XV & Venus & Adonis & Complaint (death) & $\mathrm{y}$ & Myth \\
\hline
\end{tabular}

Boyd, Heroides et Hymni, pp.1-79. Epistle numbers added.

${ }^{1}$ Ovid, Amores II.18.27-34; Raphael Lyne, 'Writing Back to Ovid in the 1560s and 1570s',

Translation and Literature, 13 (2004), pp.143-62 (p.143). Citations from the Heroides are from

Ovid, Heroides \& Amores, ed. G.P. Goold, Loeb Classical Texts (Cambridge, MA: Harvard University Press, 1976).

${ }^{2}$ Marci Alexandri Bodii Scoti Epistolae Quindecim, quibus totidem Ouidij respondet (Bordeaux, 1590). The one surviving copy is in the Bibliothèque Municipale de Bordeaux: I am grateful for their sending me a photocopy.

${ }^{3}$ M. Alexandri Bodii Heroides et Hymni ('Antwerp' [i.e. La Rochelle]: 1592), p.156 (undated letter to Cornelius Varus). In both works the poetry is in italic type, but I reproduce it normally. For the place of publication, see I.C. Cunningham, 'Marcus Alexander Bodius, Scotus' in L.A.J.R. Houwen, A.A. MacDonald and S.L. Mapstone (eds.), The Palace in the Wild: Essays on Vernacular Culture and Humanism in Late-Medieval and Renaissance Scotland (Leuven, 2000), pp.161-74 (p.162n.)

${ }^{4}$ For the settings of Boyd's 1592 Heroides, see Appendix (in front of these notes). 
${ }^{5}$ Boyd, Heroides et Hymni, sigs. Aij ${ }^{\mathrm{r}}$-A.iiijr.

${ }^{6}$ James MacQueen, 'Scottish Latin Poetry', in R.D.S. Jack (ed.), The History of Scottish

Literature, Volume 1: Origins to 1660 (Aberdeen, 1988), pp.213-26 (p.219).

${ }^{7}$ Epistolae Quindecim, sig. Aijv .

${ }^{8}$ For the opaque background, see Cunningham, p.161.

9 ‘Lepide et concinne dicta': Heroidum Epistolae P. Ouidii Nasonis et Auli Sabini Responsiones [...]

(Venice, 1588), pp.5-6, 222.

${ }^{10}$ Humanist pedagogical aims and assumptions also underpin Boyd's fragmentary, unpublished treatise De Poeta (National Library of Scotland, MS 20759, fols. 198r-203v ${ }^{\mathrm{v}}$ ). This advances a conventional humanist educational programme (quality of teacher, language, exercises, authors of escalating difficulty).

${ }^{11}$ Epistolae Quindecim, p.6 ('Esse necesse qui Nasoni respõdet, Nasonem vt referat quoque').

${ }^{12}$ Ibid., p.7 ('versuum enim suauitatem, connexionem, decursum, tenuitatem pauci subsequentur. adde Romani sermonis natiuam elegantiam, nihil fractũ, nihil obscurũ, nihil affectatum').

${ }^{13}$ Ibid. ('at Nasonis natiuum impetum arti [...] nemo in se esse putabit, qui non eodem cum illo quasi redeunte sydere se natum censet').

${ }_{14}$ 'Cum in omni genere nonnulli claruerunt, elegiam qui tersam, tenuem, latinam, concinnam saeculo daret, fuit nemo' (Heroides et Hymni, sig. Aijr). The use of 'tersam' to describe elegy is from Quintilian, Institutio Oratoria X.1.113; the others are generic terms for lyric poetry. 15 ‘Cultior Propertius, \& tutior, concinnior Tibullus; his tenuitatem, \& natiuum impetum adiecti Naso priorum primus' (Heroides et Hymni., sig. Aiijr).

16 `Hanc tenuem picturam, quam Memoriae ad aram cum tuo titulo appendeo, e veteri tua clementia respice rogo; me quoque non tibi natum modo, sed spe tuae gratiae ab omni peregrino patrocinio semper liberum adspice' (Heroides et Hymni, sigs. Aiijv - Aiiijr). ${ }^{17}$ Ibid., sig. Aiiij", pp.133-9, 133 ('musæ Pater inclyte'). Boyd also dedicated a hymn on the rose to James's Chancellor Sir John Maitland (pp.97-100). 18 See Heroides et Hymni, pp.162-3, 170-1. 
19 ‘Materia vero est ethica.i. moralis quia describit varios variorũ [?virorum], mulierumque mores, intentio poëtæ est exercendo ingenium, \& quærendo formam amoris effectus demonstrare, \& ostendere, quantum hi different in mulieribus pudicis, \& impudicis qui in alii[s] casti amoris pietatem in aliis libidinis \& furoris incontinentiam probant. Itaque aliæ ad laudem \& imitationem, aliæ ad libidinis, \& impudicitiæ detestationem memorantur' (P. Ouidii Nasonis Poetae Sulmonensis, Heroides Epistolae [Venice, 1574], p.1).

20 ‘ Illas decoro morique voluit fœminarum accomodare, quae usu domestico non ratione pure incorrupteque loqui solent' (Heroidum Epistolae [1588], p.222).

${ }_{21}$ 'Quae honeste et scite sunt dicta in Heroidum Epistolis' (ibid., p.3).

22 ‘Læsa pudicitia est, deperit illa semel' (Heroides V.104); 'est virtus placitis abstinuisse bonis' (XVII.98). Cf. Heroidum Epistolae (1588), p.4.

${ }^{23}$ Julius Caesar Scaliger, Poetices Libri Septem [1561], ed. by Luc Deitz and Gregor Vogt-Spira, 5 vols. (Stuttgart, 1994-2003), II, p.184 ('propria feminae virtus est pudicitia [...] pudicitia est constans abstinentia a venere prohibita'). Scaliger contrasts it with castitas, which is abstaining from all sexual activity whatsoever.

${ }^{24}$ Bishop Thomas Cooper (ed.), Thesaurus Linguae Romanae \& Britannicae (London, 1578), s.v. 'pudicitia'. The other main definitions are 'chastitie' and 'puritie'.

${ }^{25}$ Thesaurus (1578), s.v. 'pudor'.

${ }^{26}$ E.g. Patrick Cheney, 'Introduction: Marlowe in the Twenty-First Century', in Cheney (ed.), The Cambridge Companion to Marlowe (Cambridge, 2004), p.15; Heather James, 'Ovid and the Question of Politics in Elizabethan England', ELH, 70 (2003), pp.343-74.

27 Thesaurus (1578), 'pudicitia', 'pudor', 'pudicus', 'pudice'.

${ }^{28}$ Ovid, Heroides II.57-60, 143.

${ }^{29}$ [George Puttenham], The Arte of English Poesie (London, 1589; repr. Amsterdam \& New York, 1971), p.20.

${ }^{30}$ Everard Guilpin, 'Satyre Praeludium' (line 11), Skialetheia or A Shadow of Truth, in Certaine Epigrams and Satyres, (London, 1598), p.59.

${ }^{31}$ For queror, see e.g. Heroides I.8, II.2, 26; III.5,6, etc.; querela, I.70, II.8, etc. 
${ }^{32}$ Heroides Epistolae (1588), p.1.

33 'Nam et frequens conquestio in amoribus et verissima mors, quae a nobis amentissimis amentissimo atqui ingratissimo sexui vivitur' (Scaliger, I, p.416).

34 'carmen aptum conquestionibus' (Scaliger, III, p.200).

35 “infida, suspicax, inconstans, insidiosa, simulatrix, superstitiosa' (Scaliger, II, p.180).

${ }^{36}$ Ibid., p.184.

37 `Praecipites vero in fletum atque conquestionem feminae [...] insatiabilis enim est sexus ille rerum omnium, ut neque appetens pacari neque plenus expleri possit. Numquam sane sorti suae acquiescit' (ibid., p. 188).

${ }^{38}$ Ibid.,p. 200 ('subditur ergo constanti heroico fluxus pentameter'). The hexameter was conventionally considered heroic due to its use in epic poetry.

${ }^{39}$ Epistolae Quindecim, sig. Aiijv.

${ }^{40}$ Ibid., pp.16, 19; cf. Heroides II.103.

41 `Desine plura queri’ (Epistolae Quindecim, p.17).

42 ‘Desine crudeles [...] questus |Ducere’ (ibid, p.55).

${ }^{43}$ See Heroides IX.73-118.

$44 \quad$ Scilicet is posset magnum qui pectore robur

Continet, ac ipsas viribus arcet aquas,

Vnius in solo mulieris viuere lecto,

Et velut ad nutum semper adesse tuum.

Impiger Alcides vbi tunc, vbi robora, claua?

Qui reliquos vinco, si tibi victus ero?

(Epistolae Quindecim, p.53).

45 `Nec fuit exiguæ laudi tibi, fœmina, si tu |Cum reliquis multis Herculis vxor eras' (ibid, p.54).

46 'æquum tamèn non fuisse, vt Hercules, qui reliquos deuicit omnes, vni fæminę pareret' (ibid, p.50; my italics). 
47 `Nec labor Alcidem, neque vis furiosa, nec ensis /Vicit; at indigno fœmina ficta dolo’ (ibid, p.55).

${ }^{48}$ Heroides et Hymni, p.5.

49 'quæ iunxit connubialis amor' (ibid, p.57).

50 'At hæc epistola tota est Veneris' (ibid, p.23).

51 'Erubuit vultus ferior, motantur ocelli |Crebrius, \& motu torqueor acta meo' (ibid, p.26).

52 ‘Protinus eiicitur pudor aureus, omnis honesti |Cultus' (ibid, p.25).

${ }^{53}$ Ibid., pp.23, 27.

54 'cuperetque poëta ne Lamiæ personæ (Greek: to prepon) sibi casto sit (Greek: aprepon)' (ibid, p.23).

55 The woman behind this name, and her poetry, has perished; cf. Cunningham, p.165.

${ }^{56}$ Heroides et Hymni, p. 124.

${ }^{57}$ Ibid., pp.123-7; cf. Ovid, Metamorphoses VI.1-145.

${ }^{58}$ Ibid., p.124. Boyd makes her equal in spirit to Minerva and her superior in virtue, but adds the futility of fighting the gods ('sed quid certemus Olympo?').

59 ‘Sed nos Herculeum pensum confecimus, atque |Nunc tempus ruptâ radium suspendere tramâ' (ibid, p.127).

${ }^{60}$ Ibid., pp.163-7 (undated letter to 'M.T.', from Fontenay).

61 `Nunquam ego credam virorum eo esse inclementiam, vos vt de veteri possessione venerum, \& eloquentię deiicerent' (ibid, p.165).

62 'cùm nobiscum olim de rei summâ certaretis, acie deuictas, \& iure gentium nobis ancillas esse factas: proinde in mancipio, in potestate nostri sexus esse: siue viri sumus: siue parentes: siue domini: \& non à publicis officiis remotas modo, sed interdicta vobis veterorum sororum, musarum nimirum \& venerum contubernia, ne de re vestrâ, déque veteri dignitate cogitetis' (ibid, pp.165-6).

${ }^{63}$ Boyd's distillation of the civil law still survives in manuscript: see Cunningham, p.164n.

64 Lamia sola toro iacet ignea, lentus amator 
Friget, \& est tepido Lamia sola toro.

Ah qui conubio primùm coniunxit amantes!

Et vetuit Paphiæ libera facta sequi.

Pendeat in mediis, sitiēs vti Tantalus, vndis,

Dira nec oblatus temperet ora cibus.

(Heroides et Hymni, pp.27-8).

${ }^{65}$ Epistolae Quindecim, pp.116-122. The women featuring in these eulogies who also appear in Ovid's Heroides are (respectively) Penelope, Dido, Hypermnestra, Phyllis, Thisbe, Hero, and Sappho. Sophonisba, Paulina, Callioneira and possibly Antonia also reappear in Boyd's Heroides of 1592.

${ }^{66}$ Boyd here follows Virgil, Georgics IV.454-9.

${ }^{67}$ Heroides et Hymni, p.32 ('Chara pudicitiæ coluber me iura tuentem | sustulit').

68 At pudor humani producit semina morbi

Et timor, \& charae cura pudicitiae.

Cura premit teneras, sed quae sua vulnera tantum

Pallida detexit sola puella sapit.

(Heroides et Hymni, p.32)

${ }^{69}$ Epistolae Quindecim, pp.46-50; cf. Virgil, Aeneid IV.333-61. Boyd's Aeneas evades discussion of having sex with Dido in a cave, a key issue of both Ovid and Virgil's tellings.

${ }^{70}$ Heroides et Hymni, pp.41-2.

${ }^{71}$ Ibid., p. 65.

72 Ibid., p.65.

${ }^{73}$ Ibid., p.69.

$74 \quad$ Doctor adulterij Naso, cui mœcha volenti Iulia, legitimum cùm nequit ira modum, Castus Caesar, aït, mox Liuia lena puellam Subiicit. illa pio pectore celat opus. 
Turba senum comites olli, sed adultera semper

Iulia, spectata nec comitata viro.

(Heroides et Hymni, p.67).

75 See Suetonius, Divus Augustus LXIX, LXXI in Lives of the Caesars, ed. J.C. Rolfe, Loeb Classical Texts (Cambridge, MA: Harvard University Press, 1913; repr. 2001), pp.252-4, 256.

${ }^{76}$ See e.g. NLS, MS 20759, fol. 229r (undated letter to Boyd of Badneth); Heroides et Hymni, p.172 (undated letter from P.D. [Patrick Danthonet] to Boyd).

77 `Regem adeam mones Persarũ more, faciam quicquid potero, licet cum pituita quotidie committor, fortiter tamen \& more meo qui vitam sine laude non magnopere expetendam censeo' (undated letter to Sharp: Heroides et Hymni, p.163). 